\title{
THE EXTRATERRITORIAL ENFORCEMENT OF STATUTES IMPOSING DOUBLE LIABILITY UPON STOCKHOLDERS.
}

The pronounced tendency now prevailing in the United States to extend and more rigorously to enforce the obligations of corporations, their officers and directors, has brought with it a corresponding tendency to enlarge the obligations of stockholders. This is not entirely a logical result, for the stockholder, as such, has no direct voice in the management of the enterprise, and if he be of the bare minority, he has not even a voice in the selection of its personnel.

Along with the tremendous increase in corporate investments, however, stockholders have become so widely distributed throughout all classes of the community that the suggestions for legislation for protecting "the public" have gradually come to embrace their. interests as well, in order to prevent injustice from being visited upon them through fraud and over capitalization. In other words, the interests of stockholders can no longer be considered apart from that of "the public." But though the subject has been discussed as having a bearing on the welfare of our entire commercial system, the movement is yet only in its infancy.

The experience of Continental Europe has been essentially different from our own in this respect, for, from the very beginning of the history of the corporation considered as a commercial and legal entity; safeguards were thrown around its formation, so as to simultaneously protect the credit-extending public and the stockholder. Both in France and in Germany, the state must be taken into the confidence of the organizers (fondateurs, Griinder) and some particular arm of the government is entrusted with the task of determining ( 1 ) whether all the legal formalities have been complied with and (2) whether the capital paid in represents actual value. So too, there are further safeguards when the organizers come to sell their stock to others. ${ }^{1}$

1. See Lehman, Das Recht der Aktiengesellschaften (1898) Vol. I. p. ${ }_{363}$ et seg. 
With the details of these provisions we are not now concerned, but it is recognized that many of the evils in our own system have resulted from the extreme laxity of the law in respect of capitalization. The exact definition and the cure of these evils are, however, problems rather of economics than of law, but as so frequently happens, a certain impulse or direction has been given to the development of the law, because some economic result has been considered by the court as necessary or desirable.

It is not at all improbable that if the legislatures of the States had recognized at an early day that the evils attending the corporate form were due to the latitude given in respect of capitalization, there would have been no departure from the ordinary type of corporation, with a liability on the part of stockholders, limited to their investment. To compel strictness in rapitalization was, for a long time, considered unsuitable to a young and growing country, but in the absence of reform in this direction came a policy in some States to hold responsible the living men standing back of the lifeless and soulless entity of the corporation. An example of this policy is furnished by the Constitution of Kansas which was made to provide as follows: ${ }^{2}$

Dues from corporations shall be secured by individual liability of the stockholders to an additional amount equal to the stock owned by each stockholder, and such other means as shall be provided by law.

This provision of the Constitution stands now quite alone; there are no longer any legislative provisions in Kansas prescribing the manner of enforcing the liability, as all prior statutes relating thereto were repealed in $1903 .{ }^{3}$ The amplifying Act of $1868,{ }^{4}$ however, provided that suit might be brought by a creditor of a dissolved corporation with debts unpaid, against any stockholder holding stock at the time of dissolution, without joining the corporation. After execution had been returned unsatisfied against the corporation, execution might be issued on the same judgment, upon motion, against any stockholder, to an amount equal to the amount of stock held by him; the stockholder was then entitled to contribution from fellow-stockholders. ${ }^{4}$

No legal objection is presented in the ordinary case to the enforcement of such a liability within the State of Kansas, against one of its citizens, but as soon as an attempt is made to execute the liability without the jurisdiction in which it was enacted, numerous problems are presented. In the case of

2. Sec. 2, Art. 12.

3. Laws of $x 903$, ch. 152.

4. Gen. Stats. (1868) ch. 23. 
Whitman v. Oxford National Banks a creditor of a Kansas corporation brought an action to enforce the double liability in the Federal courts within the State of New York against a stockholder resident in the latter State. The New York law recognizes no liability to creditors of stockholders in such corporations after the capital stock has been paid in. ${ }^{\circ}$ The United States Supreme Court held that the obligation imposed by the Kansas statute was "contractual in its nature" though "statutory in its origin," and hence enforceable in a foreign jurisdiction. The reasoning of the opinion is not close and its language should be taken in a very broad sense and for the purposes of the argument then at hand, which was to demonstrate that the liability was not penal in the international sense.

We may assume that the liability is not penal, at least under the test finally adopted by the Supreme Court in Huntington $v$. Atrill, ${ }^{7}$ pursuant to which, only such laws are penal which impose punishment for an offense against the State. Though opposed to many State court decisions, ${ }^{8}$ the test is now whether the wrong sought to be redressed is a wrong to the public, or a wrong to the individual. But it is nowhere intimated that because a statute is not penal, it is therefore enforceable extraterritorially. The term "contractual" must be taken in some broader sense as applicable to an obligation resulting indirectly from some voluntary act of the stockholder, not in its usual sense of an obligation directly assumed or within the contemplation of the party when the voluntary act was performed. Even if this were not so and the obligation be deemed contractual in the strict sense, to whom was the promise made? Not to the creditor, because his debt may not even have been incurred at the time of the subscription to, or the purchase of the stock; and not to the corporation, because the creditor does not claim through it and, in fact, it is precisely the debt of the corporation which the stockholder is being asked to pay.

The Supreme Court thus gave extraterritorial force to an obligation implied only in the Constitution and laws of Kansas.

5. (1899) I76 U. S. 559 .

6. See Marshall v. Sherman (1895) I48 N. Y. 9 .

7. (I892) 146 U. S. 657 . The statute held not to be penal in the international sense was one rendering officers of a corporation individually liable for its debts in the event of filing a false report. The Supreme Court had already held that such statutes must be strictly construed. Chase $v$. Curtis (1885) 113 U. S. 452 ; Flash v. Conn (I883) 109 U. S. 371.

8. Derrickson v. Smith (1858) 27 N. J. Law 166; Halsey v. McLean, (1866) I2 Allen 438; Bank v. Price (1870) 33 Md. 487. 
As was well said by the New York Court of Appeals in refusing to enforce this same statue: "the plaintiff's right of action has no other legal or moral basis than the fiat of a legislature of another State." 9 As the statutes of one State have, ex proprio vigore, no force or effect in another, the decision must rest exclusively upon the basis of comity, although the decisions of State courts as to the extension of comity are not reviewable by the Supreme Court. ${ }^{10}$ Now, as we have seen, the State of the Federal district wherein the action of Whitman v. Oxford Nat. Bank was brought, has refused to extend to the Kansas statute the comity of its own jurisdiction, yet the Federal court, in exercise of its concurrent jurisdiction has in effect laid down a contrary rule. It is also contrary to the rule applied to the same statute in many other States. ${ }^{11}$

There are, perhaps, certain considerations other than legal which influence the Supreme Court in this class of cases. At least an intimation of this is given in the dictum of Mr. Justice Brewer in the Whitman case (supra). On page $5^{6} 3$ of the report, he says:

In view of the present tendency to carry on business through corporate instrumentalities and the freedom from personal liability which attends ordinary corporate action, it cannot be said that this limited additional remedy is open to judicial condemnation.

The significance of the decision, however, extends far beyond the "limited additional remedy" which the statute affords, for there would be no difference in principle had the statute enacted a treble, quadruple or even an unlimited liability.

The State of Minnesota has likewise embodied the principle of double liability in its Constitution. 12

Each stockholder in any corporation (excepting those organized for the purpose of carrying on any kind of manufacturing or mechanical business) shall be liable to the amount of stock held or owned by him.

9. Marshall v. Sherman (1895) I48 N. Y. 9, 24.

Io. Finney v. Guy (Ig02) I89 U. S. 335 , in which the court attempts to distinguish Whitman v. Oxford Nat. Bank (supra) and Hancock Nat. Bank v. Farnum (1900) I76 U. S. 640.

11. Bank of North America $\nu$. Ridge (1891) r54 Mass. 203; Fowler $v$. Lamson (I893) I46 Ill. 472; Crippen v. Laighton (1899) 69 N. H. 540. In another group of decisions, the denial of extraterritorial force to such statutes is placed upon the ground that the local forum is not adapted to the remedy provided. Bates v. Day (Igor) 198 Pa. 513; Bank v. Benson (1900) 106 Wis. 624; Russell $v$. Pacific $R$. Co. (1896) 113 Cal. 258.

I2. Art. I0, Sec. 3. 
The amplifying act as embodied in the Revised Statutes of 1878 and as re-enacted in $1894,{ }^{13}$ provided for sequestration proceedings in the event of an unsatisfied execution, and if it should appear that the corporation be insolvent, the court might ascertain the respective liabilities of the stockholders and compel each to pay an additional sum not exceeding the amount of his stock. Under this Act, it was held that the proceeding was in equity, to which all the creditors and all the stockholders must be parties, so that the liability might be properly apportioned. ${ }^{14}$ Accordingly, the United States Supreme Court held in Hale v. Allin$\operatorname{son}^{15}$ that the proceedings were not binding upon any who were not served, or made voluntary appearance, and the statute thus proved abortive as to non-resident stockholders.

To meet this situation, an Act was passed in $1899^{16}$ providing for a hearing upon the petition of an assignee or receiver of the corporation, or any creditor, as to the probable indebtedness of the company, the expenses of the assignment or receivership, and the probable assets available, upon which the court shall levy a ratable assessment upon all stockholders, "taking into account the probable solvency or insolvency of stockholders and the probable expenses of collecting the assessment," and shall direct its payment to the assignee or receiver. ${ }^{16}$ - The statute further provides (sec. 5) that the' assessment levied shall be conclusive against all stockholders "whether appearing or having notice thereof or not," as to all matters relating to the amount of and necessity for the assessment. ${ }^{16}$

This complete change from the originial policy of the legislature would certainly seem to have imposed new burdens on the stockholder. In a suit by a receiver of a Minnesota corporation against a stockholder, resident in Connecticut, and who became such prior to the Act of 1899 , the Supreme Court of Errors of Connecticut held ${ }^{17}$ that it was unconstitutional because of the impairment in the original obligation of the stockholder. In a well considered opinion by Mr. Justice Simeon E. Baldwin, it is pointed out that to the liability originally assumed under the original Act, there was added the liability as measured by the

13. Gen. Stats., chap. 76, sec. 5897-591r.

14. Patterson $v$. Stewart (1889) $4 \mathrm{I}$ Minn. $84 ;$ In re Martin's Estate (1894) 56 Minn. 420; Fanson v. Davison (1898) 73 Minn. 454.

I5. (I903) I88 U. S. 56.

16. Gen. Stats., chap. 272, secs. I-I2.

17. Converse v. Actna National Bank (I906) 64 At. 340. The case is now pending on appeal to the Supreme Court of the United States. 
estimate of the court as to what might be thereafter necessary for future expenses in future suits to collect what were never corporate assets, in opposition to which the stockholder might very well say: "non haec in foedera veni."

So, too, in New York, in a suit against a stockholder of the same corporation, it was held ${ }^{18}$ that irrespective of whether the statute did or did not impair vested rights, it failed to grant due process of law, in that it assumed to make the assessment proceedings binding upon stockholders not parties to it. The appearance of the corporation is not sufficient, for the receiver's right to enforce the liability depends upon his representation of the creditors, not of the corporation. Even assuming a succession to rights of the corporation, the latter would then be an adverse party to the stockholders against whom the liability was sought to be enforced and the court certainly could not acquire jurisdiction as against stockholders by making the adverse party a party to the proceeding. ${ }^{18}$

The decision in Converse v. Stewart, though not in a court of last resort, is in line with the settled law of the State. Thus in an action brought to recover the amount due from a stockholder of a bank incorporated in the State of Washington, for an equal and ratable proportion of an alleged deficiency due on account of stock ownership, pursuant to Washington laws, the Court of Appeals (per Vann, J.) said: 19

The stockholders, however, may controvert in our courts all the essential facts, such as insolvency, the amount of the deficiency, and the like, whether they are established by the judgment appointing the receiver or not. They may require strict common-law proof as to all the facts upon which the deficiency is based, and may contest any unreasonable expenditure in the conversion of assets and the collection of accounts, including extravagant allowances to attorneys or counsel.

Notwithstanding this state of the law and the sound reasoning of the courts in these decisions, the United States Supreme Court has recently taken a long step toward identifying the corporation with its individual stockholders even in other than corporate matters, by making its appearance conclusive upon them. In Bernheimer v. Converse, ${ }^{20}$ decided in May, ${ }^{19}{ }^{\circ} 7$, the defendants' testators became stockholders in the same Minnesota corporation

18. Converse v. Stewart (1905) 95 N. Y. Supp. 3ro. On appeal, after new trial, the Appelate Division approved the doctrines laid down in its former opinion. (I907) 102 N. Y. Supp. I133. The case is now on appeal to the Court of Appeals.

19. Howard v. Angle, (1900) 162 N. Y. I79.

20. (IgO7) 206 U. S. 5 I6. 
as in the Connecticut and New York litigations, long prior to 1899. The defendants urged, among other things, ( $x$ ) the unconstitutionality of the later Act for the reason that it impaired their obligations as fixed by the earlier Act; (2) the lack of due process of law in authorizing a conclusive judgment against nonresident, non-appearing stockholders; and (3) that the receiver had no title to maintain the suit. All of these objections the court overruled.

Prior to this, the court had been most careful to save these identical questions in actions not necessarilly involving them. ${ }^{21}$ Mr. Justice White expressly defined them in Evans v. Nellis. 22 In its most recent decision, the court sanctions the extraterritorial enforcement of the liability in terms which are indeed unprecise from the point of view of juridical definition. While it considers the obligation as "contractual in its nature," yet the court (per Day, J.) says" it is "not entirely contractual and springs primarily from the law creating the obligation." If this be true, why should not the right and remedy remain local under well-known principles of the conflict of laws? "If the cause of action is one that might have arisen anywhere, then it is transitory; but if it could only have arisen in one place, then it is local."24 This doctrine was recognized in a well considered case in New Hampshire involving the extraterritorial enforcement of the Kansas statute, wherein it is said:25

The organic, or statute, or common law of no State in the Union has conferred upon its courts authority to put into active operative effect, efficient per se, the statutes of another State.

In another case ${ }^{26}$ in the same jurisdiction, the obligation is declared to be a "naked, statutory liability, entirely unknown to the common law, for the indebtedness of the corporation however it may accrue, whether from the breach of a contract or the commission of a tort." The theory is in line with the view expressed nearly one hundred years ago by Judge Story, in a Federal case, ${ }^{27}$ that no action in assumpsit would lie in such cases. The New Hampshire doctrine is followed also in other jurisdictions. ${ }^{28}$

21. Bank v. Converse (1906) 200 U. S. 425.

22. (IgO2) 187 U. S. 271 .

23. At p. 529 .

24. Wharton, Conflict of Laws (1905) sec. 7r r quoting from Judge Cooley.

25. Crippen v. Laighton (I899) 69 N. H. 540, 550

26. Ricev. Hosiery Co. (1875) 56 N. H. Ir4, т28.

27. Bullardv. Bell, (1817) I Mason 243, 300 .

28. Bank v. Farnum, (1898) 20 R. I. 466; Brown v. Eastern State Co. (1883) I34 Mass. 590; semble, Lane w. Morris (185I) ro Ga. I62; see Whitford v. Railroad (186r) 23 N. Y. 465 . 
Unfortunately, Mr. Justice Holmes who doubted the result in the Bernheimer case did not amplify his views. He simply says:

I regret that the court has thought it unnecessary to state specifically what contract the stockholder is supposed to have made, as different difficulties beset the different views that might be taken.

And he adds that he finds difficulty in reconciling the construction adopted, with that given to the stronger words of section $5^{1} 5^{1}$ of the National Bank Act in McClaine v. Rankin. ${ }^{29}$ That action was brought under the Federal statute which provides that each stockholder of a national bank shall be held individually, equally, and ratably, and not one for another, for all its liabilities to the extent of the amount of his stock in addition to the amount invested. The statute of limitations of the State of Washington, wherein the action was brought, provides a three year period for actions "on contract, or liability express or implied," not in writing, and a two year period for other statutory liabilities. The court held that the shorter period applied, on the ground that the Act does not imply a promise from the stockholder as surety to the creditor for the debts of the bank, but merely imposes a liability secondary to those debts, to which, indeed, the stockholder is not a party. ${ }^{2} 9$

It is but fair to state that two of the learned justices who concurred in the Bernheimer case, dissented from the opinion of the majority in McClaine $v$. Rankin, but the latter case is strictly in harmony with the settled doctrines of the Supreme Court. Thus it has held ${ }^{30}$ that coverture is no defense to the liability imposed by the National Bank Act, which it would be, were the liability "contractual" in any but a loose sense. In fact Mr. Justice Harlan expressly states that on becoming a stockholder, the defendant "made, strictly, no direct contract with anyone."30

To the objection that the later Minnesota statute impaired obligations fixed by the earlier one, the court held that the Constitution had already fixed the maximum. Yet a reference to its wording (supra) will show that, of itself, the Constitution does not indicate to whom the liability runs, and without an obligee, the provision amounts to no more than a declaration of principle.

29. (1905) 197 U. S. 154, 16r.

30. Christopher v. Norvell (1905) 20r U. S. 216. Accord, Robinson v. Turrentine (1894) 59 Fed. 554, 555, in which the court said that the obligation grows wholly out of the Act of Congress. So too in McDonald $v$. Thompson (1902) I84 U. S. 7I, 73, the court said: "There was no contract in writing with the creditors or cepositors of the bank, and none with the bank itself to which the receiver could be said to be a privy, except to pay for the stock originally issued." 
Furthermore, it does not seem reasonable to justify the increased burdens as being incidental to a change in the remedy, when that "remedy" consists of an assessment embracing such purposes as the "probable" expenses of the receiver in making investigations, and conducting suits, successfully or not, against other stockholders. We do not wish to enter too much at length upon the discussion of this question, as its significance is limited to the rights of stockholders who became such prior to the recent Act. It suffices to say that where the change of remedy effects a substantial change in the rights of the parties, statutes making the change have repeatedly been held unconstitutional. ${ }^{31}$

The importance of the decision lies in the fact that it practically deprives the stockholder of his day in court on every question except the fact of stockholdership. As to the regularity of the proceeding in the foreign court, the necessity for the receivership, the validity of the claims alleged against the corporation, the solvency or insolvency of the other stockholders, and what should be the reasonable expenses of necessary litigation, he is denied a hearing. The doctrine adopted by the court is that the stockholders are represented by the corporation; but it is obvious that a constructive representation such as this must work peculiar hardship on the absentee stockholders. Normally, the corporation for all practical purposes will have ceased to exist and, in fact, in the principal case, the company, at the time of the sequestration proceeding, had not only ceased to do any business, but had been stripped of all its property and franchises. It was therefore incapable in law and fact, of representing the stockholders or any one else. ${ }^{32}$ Furthermore, it is doubtful whether the statute itself contemplates any such representation, the legislature must have foreseen that at the time of the hearing, the corporation is likely to be defunct, and the only contesting parties will be the receiver or creditors on the one hand and the officers or stockholders on the other.

Finally, as to the receiver's capacity to sue in a foreign jurisdiction, the court upheld his right upon the theory that the statute made him a "quasi-assignee" for the creditors. ${ }^{33}$ The

31. State National Bank v. Sayward (1899) 9r Fed. 443; Knickerbocker Trust Co. v. Cremen (I905), I40 Fed. 973; Harrison v. Remington Paper Co. (1905) 140 Fed. 385; Allis v. Insurance Co. (1877) 97 U. S. 144; Seibert v. Lewis (1887) I22 U. S. 284, 297, 299.

32. Danforth v. Chemical Co. (1897) 68 Minn. 308; Schrader v. Bank (1890) I33 U. S. 67, 76; Covell v. Fowler (1906) r44 Fed. 535, 538.

33. P. 534 . 
statute nowhere indicates this, but, on the contrary, speaks throughout of the receiver as being "of" or "for any such corporation." As the receiver could only take title to corporate assets and as the right to sue is vested in the creditors and not in the corporation, the receiver must be purely a statutory one and therefore properly within the rule of Hale v. Allinson, (supra).

In conclusion, it may be said that the result reached is another proof of the dangers involved in the doctrine of judicial construction. By this process, the most deeply rooted principles of jurisprudence may gradually be made to give way. A foreign receiver may now sue in a local jurisdiction, as constructive ("quasi") assignee and successfully urge a conclusive assessment made in the foreign jurisdiction pursuant to a contract wholly constructive, against stockholders, in fact absent and without notice, but constructively represented by a corporation, in fact defunct, but constructively still able to represent its stockholders.

New York.

Arthur K. Kuhn. 